\title{
LIMITS OF THE RIGHT OF SELF-DEFENCE OF INDIVIDUALS IN INTERNATIONAL CRIMINAL LAW
}

\author{
Paweł Mielniczek*
}

\section{Introduction}

The purpose of this article is to delineate the limits and the detailed content of the right of self-defence of individuals in international criminal law. Since there is no formal limitation of the right of self-defence as regards certain crimes ${ }^{1}$, determining whether this right is applicable in certain particular situations requires an analysis of its rules of application, such as reasonability, imminence and proportionality. The article uses a twostep method. Firstly, it attempts to clearly define the situations which fall under the discussed right of self-defence. Secondly, it confronts the rules governing the right of self-defence with the arguments which give rise to the greatest difficulties.

* Paweł Mielniczek, University of Warsaw.

1 H. Tonkin, Defensive force under the Rome Statute, 'Melbourne Journal of International Law' 2005, vol. 6, p. 87. 


\section{General rules governing the right of self-defence of individuals}

The most authoritative international law provision on individuals' right of self-defence is art. 31 para 1(c) of the Rome Statute of the International Criminal Court (1998) ${ }^{2}$, hereinafter referred to as the Rome Statute. Similarly to art. 51 of the Charter of the United Nations (1945) ${ }^{3}$, hereinafter referred to as the UN Charter, which enshrines the right to individual or collective self-defence of states ${ }^{4}$, it excludes criminal liability not only for one's own defence, but also for one's defence of others. Furthermore, the right of self-defence of individuals extends to the protection of property. However, the right of self-defence of property is limited to cases of war crimes and refers only to property which is essential for the survival of the person or another person or property essential for accomplishing a military mission ${ }^{5}$. Both of the protected values, i.e. person and property, can be reasonably defended against an imminent and unlawful use of force in a manner proportionate to the degree of danger facing the person or the other person or property protected. Any person who acts in this way is not criminally liable. Finally, art. 31 of the Rome Statute emphasises the practical assessment of certain circumstances, providing that the fact that the person was involved in a defensive operation conducted by forces shall not in itself constitute a ground for excluding criminal liability ${ }^{6}$.

These introductory remarks allow us to indicate the first area which is clearly situated beyond the limits of the discussed right. Academic writing seems not to dispute that, as regards genocide, crimes against humanity and war crimes, in practice only liability for the last mentioned type can

2 Polish O. J. 2003, No 78, Item 708.

3 Polish O. J. 1947, No 23, Item 90.

4 Next to the rights to self-defence of states and individuals, Frits Kalshoven and Thyla Fontein distinguish the right to unit self-defence, which is named 'a notion generally accepted in military practice without having a firm legal basis in most countries'. See F. Kalshoven, T. Fontein, Some Reflections on Self-defence as an Element in Rules of Engagement, [in:] M. Matthee, B. Toebes, M. Brus (eds.), 'Armed Conflict and International Law: In Search of the Human Face. Liber Amicorum in Memory of Avril McDonald', T.M.C. Asser Press, The Hague 2013, p. 97.

5 See also A. Van Verseveld, Mistake of Law, Excusing Perpetrators of International Crimes, T.M.C. Asser Press, The Hague 2012, p. 152.

6 See Prosecutor v. Dario Kordić \& Mario Čerkez, Case no IT-95-14/2-T ICTY T. Ch., Judgment, 26.02.2001, para 452. 
be mitigated by reliance on the right of self-defence ${ }^{7}$. Firstly, as H. Tonkin notes, the very definition of the crime of genocide is incompatible with the notion of self-defence, i.a. for the reason that its victim is a group defined on the grounds of national, ethnical, racial or religious allegiance ${ }^{8}$. Secondly, in order for the act to constitute part of a widespread or systematic attack directed against any civilian population, there must exist a certain nexus between the actions of the defendant and a broader campaign. According to $\mathrm{H}$. Tonkin, the circumstances authorising acts of self-defence would negate any such nexus ${ }^{9}$. Moreover, the fact that the definition of crimes against humanity contains an element of 'attack' indicates its incompatibility with art. 31 par. 1(c) of the Rome Statute.

As regards crime of aggression, Jan Klabbers notes that, as in the case of the crime of genocide, aggression cannot be committed by a single individual $^{10}$. Malcolm N. Shaw further states that it is 'unclear what differences may exist between the state's act of aggression and the individual's crime of aggression ${ }^{11}$. Although no binding definition of the crime of aggression exists in international treaty law, the most authoritative definition to date, drafted as art. 8 bis of the Rome Statute states that:

[f]or the purpose of this Statute, 'crime of aggression' means the planning, preparation, initiation or execution, by a person in a position effectively to exercise control over or to direct the political or military action of a State, of an act of aggression which, by its character, gravity and scale, constitutes a manifest violation of the Charter of the United Nations ${ }^{12}$.

In certain circumstances, the act of an individual who exercises effective control or directs the political or military action of the state, can be considered both from the perspective of art. 51 of the UN Charter (as

A. Van Verseveld, op. cit., p. 152.

8 H. Tonkin, op. cit., p. 109.

9 Ibid., p. 114.

10 J. Klabbers, International Law, Cambridge University Press, Cambridge 2013, p. 224.

11 M. Shaw, International Law, 6th edn., Cambridge University Press, New York 2008, p. 439.

12 Amendments to the Rome Statute of the International Criminal Court. Kampala, 11 June 2010. Adoption of Amendments on the Crime of Aggression, U.N. Doc. C.N.651.2010. TREATIES-8 (Depositary Notification). 
an act of the state $)^{13}$ and for the purposes of individual criminal liability. In this respect, even if the political or military action of the state exceeds the limits set out in art. 51 of the UN Charter, it still remains necessary to determine the scope of responsibility of a particular individual, who can still potentially claim to have acted in individual self-defence ${ }^{14}$. At the same time, it is possible that the actions of a military commander are not attributable to any state and, therefore, the right of self-defence of individuals remains the only applicable standard ${ }^{15}$.

In Prosecutorv. Dario Kordić \& Mario Čerkez, the International Criminal Tribunal for the Former Yugoslavia stated that that, although its statute does not contain any provision on self-defence ${ }^{16}$, such 'defences' form a part of the general principles of criminal law which the International Tribunal must take into account in deciding the cases before it. Furthermore, the Tribunal stated that the principles of self-defence enshrined in art. 31 par. 1(c) of the Rome Statute, reflect provisions found in most national criminal codes and may be regarded as constituting a rule of customary international law ${ }^{17}$.

Since the cited Rome Statute was adopted in 1998, most pleas raised in previous international criminal trials, with respect to the self-defence, were based on the concept of the right of self-defence of states. For instance, after the experiences of Nuremberg, the Tokyo defence lawyers argued that the Japanese leaders believed they were fighting for national survival. They sought to support such submissions claim by relying on the comments of

13 On the right of self-defence of states, see J. Kammerhofer, Uncertainties of the Law on Self-Defence in the United Nations Charter, 'Netherlands Yearbook of International Law' 2005, vol. 35, pp. 143-204.

14 See E. David, Self-Defence and State of Necessity in the Statute of the ICC, [in:] J. Doria, H. Gasser and M. Bassiouni (eds.), 'The Legal Regime of the International Criminal Court. Essays in Honour of Professor Igor Blishchenko', Martinus Nijhoff Publishers, Leiden 2009, p. 758.

15 For instance on the attribution of the responsibility for Terrorist Attacks of 11.9.2001 to Afghanistan, see M. Lehto, Indirect Responsibility for Terrorist Acts. Redefinition of the Concept of Terrorism Beyond Violent Acts, Martinus Nijhoff Publishers, Leiden 2009, pp. 391-393.

16 It is the Statute of the International Criminal Tribunal for the Former Yugoslavia, U.N. Doc. No S/Res/827 (1993) with further amendments. Moreover, I. Marchuk found no such provision in any 'legal instruments of international criminal courts and tribunals, except for the Rome Statute'. See I. Marchuk, The Fundamental Concept of Crime in International Criminal Law, A Comparative Law Analysis, Springer, Berlin 2014, p. 268.

17 Prosecutor v. Dario Kordić \& Mario Čerkez, supra, paras 449-451. 
Frank Kellogg, who maintained that the anti-war pact of his name ${ }^{18}$ did not preclude the 'unrestricted right of self-defence' ${ }^{\text {'19. }}$. Neither the state nor the individuals involved in state activities can be held responsible for any acts of a state which are legitimate under art. 51 of the UN Charter. However, S. Darcy notes that, pursuant to the last sentence of art. 31 par. 1(c) of the Rome Statute, it is not permitted to assert that, merely because a particular use of armed force is defensive and does not contravene the ius ad bellum, any measures taken pursuant to such use of force are not unlawful ${ }^{20}$. As the Appeals Chamber of the Special Court of Sierra Leone stated in the case of Fofana and Kondewa, the reasonable belief of fighting in a 'just cause', such as acting in defence of constitutionality by engaging in a struggle or a fight that was geared towards the restoration of an ousted democratically-elected government, cannot in itself be considered as a defence to criminal liability, but rather as a motive to be taken into account during sentencing ${ }^{21}$. The circumstances pertaining to the conduct of an individual extend beyond the conduct attributable to a state and thus enable different outcomes in applying these two variants of the right of self-defence in any particular case. For these purposes, the responsibility of states has been finally differentiated from the responsibility of commanders and other superiors in the post-World War 2 trials, as now enshrined in art. 28 of the Rome Statute.

\section{Reasonable acts of defence against an imminent and unlawful use of force}

The usage of the term 'reasonable' in the wording of art. 31 par. 1(c) of the Rome Statute entails two different, but equally correct, implications. Firstly, in order to act within the limits of the right of self-defence, a person shall reasonably believe that he faces an imminent danger of unlawful

18 Polish O. J. 1929, No 11, Item 88.

19 K. Sellars, Crimes against Peace and International Law, Cambridge University Press, New York 2013, pp. 209-213.

20 S. Darcy, Defences to International Crimes, [in:] W. Schabas and Nadia Bernaz, 'Routledge Handbook of International Criminal Law', Routledge, New York 2011, p. 237.

21 Fofana and Kondewa, Case no SCSL-04-14-A, Special Court for Sierra Leone, Appeals Judgment, 28.5.2008, para 523. 
harm ${ }^{22}$. As I. Marchuk has noted, the principle of reasonability allows to excuse the person who was wrong in estimating the danger of the violence, but had acted with due diligence on the evaluation of all the circumstances. In particular, the honest belief of the defendant must be based on a 'good reason ${ }^{23}$. This requirement, applied i.a. by the European Court of Human Rights $^{24}$, reflects a due balance between the objective and subjective models of reasonableness.

Secondly, the concept of necessity is undisputedly listed as one of the requirements for excluding criminal responsibility under the right of self-defence in international criminal law ${ }^{25}$. However, the Rome Statute does not require the defence to be necessary. In this respect, the principle of reasonability not only compensates the absence of this expression, but also seems to be more adequate. The test of necessity is interpreted as a requirement that the goals of self-defence (for example halting an attack, repelling it and recovering occupied territory) cannot be achieved by the applied form of reaction (use of force) and that the degree of such reaction cannot exceed what is reasonably required for such purposes ${ }^{26}$. The more dangerous the weapons that are used in defence, the higher the threshold of necessity ${ }^{27}$. The same refers to the level and imminence ${ }^{28}$ of danger to values threatened by the act in self-defence. Consequently, Jan Römer

22 I. Marchuk, op. cit., p. 266. In this respect, Hannah Tonkin points the Australian variant of this test, which examines whether the defendant 'believed on reasonable grounds that it was necessary in self-defence to do what he or she did'. See H. Tonkin, op. cit., p. 94.

23 Ibid., p. 267.

24 McCann and Others v. the United Kingdom, Application no. 18984/91, ECHR Judgment of 27.09.1995, para 200, confirmed in Gülv. Turkey, Application no. 22676/93, ECHR Judgment of 14.12.2000, para 78.

${ }^{25}$ See for instance Prosecutor v. Dario Kordić \& Mario Čerkez, supra, para 449, and I. Marchuk, op. cit., p. 269.

${ }^{26}$ C. Greenwood, Self-Defence, 'Max Planck Encyclopedia of Public International Law', 2011, para 27.

27 I. Marchuk, op. cit., p. 267.

${ }^{28}$ In this respect, there is no right to pre-emptive self-defence. On this concept, see N. White, The Road to Kandahar: British Military Interventions and International Law, [in:] K. Kaikobad, M. Bohlander (eds.), 'International Law and Power. Perspectives on Legal Order and Justice. Essays in Honour of Colin Warbrick', Martinus Nijhoff Publishers, Leiden 2009, p. 490-495, and G. Andreopoulos, R. Barberet, J. Levine (eds.), 'International Criminal Justice. Critical Perspectives and New Challenges', Springer, New York 2011, p. 43-48. 
states that killing in self-defence must constitute a last resort, i.e. it must be absolutely necessary in certain circumstances ${ }^{29}$.

Accepting the differentiation of standards of necessity, such as absolute necessity or military necessity ${ }^{30}$, brings us to a conclusion that, depending upon the applicable circumstances, including the level of threat, there are various margins of discretion bestowed upon a person acting in self-defence. Consequently, at a certain point the notion of necessity inevitably loses its technical character. In particular, requiring every act of self-defence to be necessary to repel an attack would in fact prohibit reliance upon this defence in seemingly hopeless situations. Accordingly, it is best to regard the requirement of necessity as included in the broader principle of reasonableness, being a threshold which delineates the limits of the right of self-defence of individuals. The concept of reasonableness is also useful in addressing cases involving provocation. It enables a deviance from certain otherwise applicable rules, such as the requirements that the provocation should aim at causing the attack instead of merely offending the potential attacker, and weighs the totality of the circumstances, thereby avoiding any assessment of this issue in isolation from other rules governing the right of self-defence ${ }^{31}$.

Next, the requirement for an act to be defensive reflects the consensus that the main purpose of self-defence is to repress the attack and not to punish an attacker ${ }^{32}$. The need for an investigation or adjudication as to whether a claim of self-defence was in fact aggressive, was emphasised by $\mathrm{H}$. Lauterpacht ${ }^{33}$, whose opinion was subsequently recalled in the Nuremberg trials ${ }^{34}$. Also, according to Hannah Tonkin, the unlawful

29 J. Römer, Killing in a Gray Area between Humanitarian Law and Human Rights, How Can the National Police of Colombia Overcome the Uncertainty of Which Branch of International Law to Apply?, Springer, Berlin 2010, p. 98.

30 See also Prosecutor v. Dario Kordić \& Mario Čerkez, supra, para 451, where the International Criminal Tribunal for the Former Yugoslavia adopted a view that in relation to the specific circumstances of war crimes, the Rome Statute provision on self-defence takes into account the principle of military necessity.

31 J. Moore, Reasonable Provocation: Distinguishing the Vigilant from the Vigilante in Self-Defense Law, 'Brooklyn Law Review’ 2013, vol. 78, p. 1698.

32 I. Marchuk, op. cit., p. 267.

$33 \mathrm{H}$. Lauterpacht, The Function of Law in the International Community, Oxford University Press, New York 1933, p. 261.

34 S. Sayapin, The Crime of Aggression in International Criminal Law, Historical Development, Comparative Analysis and Present State, T.M.C. Asser Press, The Hague 2014, p. 111. 
user of force must be the target of, and not merely the reason for, the defendant's act ${ }^{35}$. The above corresponds with the notion of imminence, laid down expressis verbis in art. 31 par. 1(c) of the Rome Statute. One of the first, and sill highly authoritative, definitions of imminence was formulated in the $19^{\text {th }}$ century Caroline case, concerning a dispute between the USA and the United Kingdom. Accordingly, the underlying use of force must be 'instant, overwhelming and leaving no choice of means, and no moment for deliberation' ${ }^{36}$. The first acts in self-defence become legitimate at the moment when the person reasonably believes that the aggressor has proceeded from the phase of preparation to taking direct steps towards an unlawful use of force. The self-defensive action must not take place after the danger of an imminent and unlawful use of force has ended ${ }^{37}$. Moreover, since merely being part of a crowd entails the risk of imminent physical contact, this term should be interpreted through the prism of the term 'danger', which constitutes a safeguard against abuses in this respect ${ }^{38}$.

Similarly to the timing, the question of unlawfulness also pertains to the belief of the defender. In this respect, the only requirement is that such belief must refer to the norms binding the attacker at the moment of an imminent use of force. Acts of self-defence should be ceased once the defender gains a good reason to believe that the use of force is lawful. For instance, the owner of an illegal facility realises that his family compound is being invaded not by his competitors, but by law enforcement officers, and that their activities are connected with his criminal behaviour. Conversely, the right of self-defence also constitutes a safeguard against the unjust excesses of government ${ }^{39}$. In the context of international criminal law, the 'unlawful' use of force does not necessarily have to violate domestic

35 H. Tonkin, op. cit., p. 104.

${ }^{36}$ C. Greenwood, Caroline, The, 'Max Planck Encyclopaedia of Public International Law' 2009, para 5. See also M. Gillett, The Anatomy of an International Crime: Aggression at the International Criminal Court, 'International Criminal Law Review' 2013, vol. 13, no 4, p. 19.

37 L. Van den hole, Anticipatory Self-Defence Under International Law, 'American University International Law Review' 2003, vol. 19 no 1, pp. 104-105.

38 See also H. Tonkin, op. cit., p. 97-99, who emphasises the role of international case-law in establishing a more detailed meaning of the term 'imminence'.

39 See also R. Dowlut, The Right to Keep and Bear Arms: A Right to Self-Defense Against Criminals and Despots, 'Stanford Law \& Policy Review' 1997, vol. 8, p. 25. 
legal norms, since the content of the latter must be consistent with state obligations under international criminal $\mathrm{law}^{40}$.

After clarifying the limits of the use of force in reference to the aspects of imminence and unlawfulness, we can address the more difficult question of defining the use of force itself. A comprehensive analysis of the UN Charter allowed Oliver Dörr to conclude that the notion of 'force', as used in this document, is limited to armed or military force and does not extend to economic and political coercion ${ }^{41}$. Transferring such analysis to the self-defence of an individual, we could consider it in terms of physical violence. However, the contemporary world delivers a growing number of non-physical dangers which require response. For instance, the need for an effective self-defence against cyber-attacks raises questions about counter strikes grounded in the principles of mitigation. As J. Kesan and C. Hayes argue, self-defence is accepted as an essential element of protection in virtually all other legal contexts ${ }^{42}$. Accordingly, although the aforementioned provision of Rome Statute pertains to the use of force, understood as physical force, we can look for similar concepts of self-defence with respect to unlawful, but non-forcible, impingements upon one's rights. The difference between these concepts and the right of self-defence enshrined in art. 31 par. 1(c) of the Rome Statute would be that it is only the latter which authorises the use of defensive physical force.

\section{The subjects and objects of defence}

The discussed threat must refer to the 'protected person or property'. Similarly to the right of self-defence of states ${ }^{43}$, the person acting in defence need not be at risk himself. Nor is he under any specific duty to protect others. However, contrary to that, the International Court of Justice found with respect to states ${ }^{44}$ that it is not possible to assume that the victim

40 See e.g. art. 21(c) of the Rome Statute.

41 O. Dörr, Use of Force, Prohibition of, 'Max Planck Encyclopedia of Public International Law' 2011, paras 11-12.

42 J. Kesan, C. Hayes, Self Defense in Cyberspace: Law and Policy, 'Illinois Public Law Research Paper' 2011, no 11-16, p. 31.

43 C. Greenwood, Self-Defence, op. cit., para 39.

44 Military and Paramilitary Activities in and against Nicaragua (Nicaragua v. United States of America), Merits, Judgment. I.C.J. Reports 1986, pp. 121-122. 
should have previously requested assistance. According to the specifics of the right of self-defence of individuals, including the immediate character of their defensive acts, the test as to whether or not any express or implied consent of the victim existed also seems to leave room for uncertainty. Accordingly, an answer to the question whether a certain act in defence of other person was authorised, can only be answered according to all the circumstances, with no more detailed rules at this level of generality.

According to Iryna Marchuk, in concerning the defence of property 'it appears unclear what degree of force may be applicable"45. In particular, she expresses the concern that a too far-reaching interpretation of this provision would lead to the conclusion that 'military personnel may be exculpated from crimes directed against the civilian population' by invoking the 'self-defence justification in the protection of military property' ${ }^{46}$. In this respect, the author notes that the strictly objective 'reasonable person' standard would not help much in assessing the conduct in the 'turbulent situation of an armed conflict or a widespread attack against the civilian population'. Rather, she recommends relying on a subjective approach to reasonableness, as a safety valve in a complex context in which international crimes occur ${ }^{47}$.

The assessment as to whether or not an act of self-defence was lawful can be compared to the steps followed by the European Court of Human Rights in evaluating whether an interference with certain human rights was arbitrary or not. In delivering judgments, it is firstly determined whether or not the relevant limitations pursued a legitimate aim and secondly, whether or not the adopted measures were necessary and proportionate to achieve such purposes ${ }^{48}$. These considerations indicate that the questions of who or what could be defended have been clearly defined in the Rome Statute, with no real need for further comment. The limits of the right of self-defence can be rather found within the tests of reasonableness, necessity and proportionality, which are applied in reference to the purpose of the defence, i.e. the protection of oneself, another person or, as regards war crimes, property which is essential for the survival of the person or another person or property which is essential for accomplishing a military mission.

48 See for instance Olsson v. Sweden (No 1), Application no. 10465/83, ECHR Judgment of 24.03.1988, para 67 . 


\section{The requirement of proportionality to the degree of danger}

According to art. 31 par. 1(c) of the Rome Statute, a person's defence must be proportionate to the degree of danger facing him or the other person or property protected. The requirement of proportionality entails balancing the relative value of the rights at stake ${ }^{49}$. The outcome of such a test is not confined to answering the question on the exclusion of criminal responsibility. In the event that the limits of self-defence as a 'right' are overstepped, the circumstances of the abuse the self-defence right may still mitigate the severity of the penalty or the classification of crime, for instance as manslaughter instead of murder ${ }^{50}$.

The main problem regarding proportionality pertains to determining the precise borderline between what is and what is not proportionate. It is insufficient to take into account and correctly assess all of the circumstances of the case. While it is undisputed that the right of self-defence authorises placing in danger a value equal to the one defended ${ }^{51}$, the Rome Statute does not describe the minimal ratio between the legitimate interests at stake. As the International Criminal Tribunal for the Former Yugoslavia has held, art. 31 par. 1(c) reflects the contents of respective domestic law provisions in the world ${ }^{52}$. For instance, Polish jurisprudence interprets a similar provision on proportionality as prohibiting the 'excessive' disproportion between the rights at stake. Lech Gardocki recommends a narrow interpretation of what is incommensurate, in order not to set undue limits on the right of self-defence. He writes, for instance, that killing in defence against rape or injuring a person attempting to commit an abduction would fall within the legitimate scope of the right of self-defence. The author proposes that reference to 'defence disproportionate to the danger' should be understood in the social sense ${ }^{53}$. Accordingly, the normative standard of proportionality can be affected by the social background of the case.

49 I. Marchuk, op. cit., p. 268.

50 Ibid.

51 R. Otto, Targeted Killings and International Law, Springer, Heidelberg 2012, pp. 78-94.

52 Prosecutor v. Dario Kordić \& Mario Čerkez, Case no IT-95-14/2-T ICTY T. Ch., Judgment, 26.02.2001, paras 449-451.

53 L. Gardocki, Prawo karne [Criminal law], 16 ${ }^{\text {th }}$ Edition, C.H. Beck, Warsaw 2010, pp. 116-117. 
One may attempt to compare legal provisions governing self-defence with provisions governing a state of necessity. However, the latter vary considerably across different jurisdictions and there is no equivalent included in the Rome Statute. For instance, German criminal law limits states of necessity to situations wherein a person, faced with an imminent danger to a legal interest which cannot otherwise be averted, commits an act to avert such danger from himself or another, if the protected interest substantially outweighs the interest thereby interfered with ${ }^{54}$. Conversely, Poland's Criminal Code requires that the sacrificed interest does not represent a value evidently higher than the right protected ${ }^{55}$. This apparent lack of consensus is particularly perplexing, since it does not help to decide whose interests should prevail in cases of self-defence under international criminal law.

In the opinion of M. Dixon, contrary to domestic criminal law, the availability of defences such as self-defence, necessity and insanity for international crimes is controversial, given the nature and extent of the acts committed ${ }^{56}$. However, as was mentioned in the introduction to this article, there is no formal limitation of the right of self-defence with respect to certain, most grave crimes ${ }^{57}$. In practice, it is the requirement of proportionality which can serve as the relevant threshold. Viewed from this perspective, we can understand the view of the International Criminal Tribunal for the Former Yugoslavia that, since the involvement of a person in a defensive military operation does not in itself constitute a ground for excluding criminal responsibility, any argument based on self-defence must be assessed on its own facts and in the specific circumstances relating to each charge ${ }^{58}$.

While that there is no dispute that the very definition of the crime of genocide and crimes against humanity precludes the exclusion of responsibility for having committed such crimes on the grounds of acting in self-defence, the requirement of proportionality must remain the main landmark in this respect. Going one step further and listing the norms of international criminal law which cannot be interfered with by an act

54 German Criminal Code (Federal Law Gazette of 13.11.1998, I p. 3322 with further amendments), p. 34.

55 Polish O. J. 1997, No 88, Item 553 with further amendments, p. 26 para 2.

56 M. Dixon, R. McCorquodale and P. Williams, Cases and Materials on International Law, 5th edn., Oxford University Press, New York 2011, p. 551.

57 H. Tonkin, op. cit., p. 87.

58 Prosecutor v. Dario Kordić \& Mario Čerkez, supra, para 452. 
of self-defence would inevitably lead to the creation of legal loopholes. In addition, as public international law evolves with growing international consensus, the changing catalogue of international crimes requires fundamental clarity as regards the general principles of criminal law. Therefore, the most certain way to reconcile such opposite aims is to assume that the requirement of proportionality contains an indication that there are certain non-derogable rights ${ }^{59}$, similar to the solutions adopted i.a. in art. 4 of the International Covenant on Civil and Political Rights (1966) ${ }^{60}$ and art. 15 of the European Convention on Human Rights (1950) ${ }^{61}$. For instance, if an attack has been committed by more than one person simultaneously, it would be disproportionate to torture one of them in order to gain information or advantage against his companion(s), even if this would transpire to be absolutely necessary for the purposes of an ongoing defence $^{62}$. Nevertheless, aside from such general consensus, there still remain doubts as regards the existence of certain extreme circumstances which would justify the use of torture, especially in the context of terrorism and suicide bombers ${ }^{63}$.

\section{Final remarks}

Similarly to what Christopher Greenwood has said about art. 51 of the UN Charter, the Rome Statute also does not create the right of self-defence, but rather confirms the existence of such a customary international law norm and sets the limits for it ${ }^{64}$. The broadest limitation of the right of self-defence of individuals in international criminal law lies within

59 Terminology used in L. Garlicki (ed.), Konwencja o Ochronie Praw Człowieka i Podstawowych Wolności, Komentarz do artykułów 1-18, Tom I [Convention for the Protection of Human Rights and Fundamental Freedoms, Commentary to articles 1-18, Vol. I], C.H. Beck, Warsaw 2010, p. 481.

60 Polish O. J. 1977, No 38, Item 167.

61 Polish O. J. 1993, No 61, Item 284 with further amendments.

62 On the issue of torture in self-defence and the approach of U.S. government, see W. Kaleck and others (eds.), International Prosecution of Human Rights Crimes, Springer, Berlin 2007, pp. 178-181.

63 M. Wade, A. Maljević (ed.), A War on Terror? The European Stance on a New Threat, Changing Laws and Human Rights Implications, Springer, New York 2010, p. 430.

${ }_{64}$ C. Greenwood, Self-Defence, op. cit., para 3. On the historical approaches to self-defence, see K. Sellars, op. cit., pp. 213-215. 
the requirement of imminence. The state of necessity, which often leaves no moment for deliberation, leads to opinions such as those which hold that the individual right to personal defence must imply some right to defensive training and to the possession of certain types of defensive arms ${ }^{65}$, outside the scope of international criminal law. Next, the requirement of reasonability of defensive acts enables a proper assessment of all the relevant circumstances, but is it the principles of necessity and proportionality which demarcate the most precise boundaries between permissible and illegitimate acts of self-defence in international criminal law. Moreover, although these legal boundaries overlap with the factual borderline between what leads to peace and order, and what constitutes a danger thereto, any effective safeguarding of the values protected by the limits of the right of self-defence requires the adoption of a broader approach and a consideration of the factors which cause military and political leaders to overstep the standards discussed in this article ${ }^{66}$.

By way of summary, art. 31 par. 3 of the Rome Statute allows the International Criminal Court to consider further grounds for excluding criminal liability, other than those referred to in art. 31 par. 1. This applies only to situations where such a ground is derived from applicable law, determined according to art. 21 of the Rome Statute. However, for instance, using this provision to exclude criminal liability for the defence of property other than property which is essential for the survival of the person or another person or property which is essential for accomplishing a military mission, would not affect the content of the right of self-defence under international criminal law, but would impact upon the application thereof to a certain degree. Since the additional grounds for excluding criminal responsibility must be 'other' than those enshrined in art. 31 par. 1 of the Rome Statute, it is impossible to apply a different concept of self-defence which is incompatible with its international criminal law equivalent.

65 See D. Kopel, P. Gallant and J. Eisen, The Human Right of Self-Defense, 'BYU Journal of Public Law' 2008, vol. 22, p. 119. See also N. Lund, The Second Amendment and the Inalienable Right to Self-Defense, 'George Mason Law \& Economics Research Paper' 2014, no 14-11.

66 See also K. Eichensehr, W. Reisman (eds.), Stopping Wars and Making Peace: Studies in International Intervention, Martinus Nijhoff Publishers, Leiden 2009. 